UDK: 008:177.7/.8

Izvorni naučni rad

Primljeno: 9.5.2019.

Prihvaćeno za štampu: 31.5.2019.

dr.sci. Emin Mesić, docent

dr.sci. Sena Družić, docent

Univerzitet u Bihaću

Islamski pedagoški fakultet

tvusk@net.hr

senadruzi@@yahoo.ca

\title{
KULTURA KAO TEMELJ SOCIJALNE INTERAKCIJE
}

\section{Sažetak}

Komuniciranje nije samo sebi svrha jer je njegov smisao u sticanju $i$ artikuliranju znanja i razmjeni stečenog iskustva. U oblasti komunikologije postoje kategorije koje, sjedne strane čine područje pronalaženja, registriranja $i$ odašiljanja informacija, dok na drugoj strani komunikologija nastoji humaniziranjem verbalnog $i$ neverbalnog jezičkog diskusa nivo ljudske komunikacije podici na viši nivo. Otuda i potreba da se u edukativnom procesu socijalnog rada i općenito rada u društvenim djelatnostima, osigura viši nivo izučavanje interpersonalnih komunikacijskih procesa i vještina.

Ključne riječi: komunikacija, informacija, interakcija, kategorija, povratna informacija, komunikologija.

\section{Uvod}

Komuniciranjem saopštavamo svoje potrebe, stavove i namjere drugim ljudima. Naše poruke koje šaljemo ne prenosimo samo riječima, već i pokretima, mimikom, odjećom, organiziranjem vremena, pa čak i mirisima, što upućuje na tzv. neverbalnu komunikaciju odnosno svojevrsni „nijemi jezik“ koji čovjek posjeduje i koji je najčešće izvan naše kontrole.

Ljudi su se oduvijek prema pismu i pismenosti odnosili s poštovanjem, a pismeni ljudi uživali su ugled u svojoj okolini. Marshall McLuhan u svojoj knjizi „Poznavanje opštila čovjekovih produžetaka“ navodi 
reakcije pripadnika jednog afričkog plemena pri susretu sa pismom. On je sa ushićenjem uzviknuo da su to riječi „uhvaćene u klopku“, poistovjećujući to sa podvigom kada lovac uhvati životinju. Zapravo, ovladavši kulturom pismenosti čovjek je počeo da gospodari riječima, čime je njegova lingvistička kompetencija sve više postajala znanje o jeziku i govoru koje uključuje i neverbalne komunikacijske simbole koje danas poznajemo kao tzv. parajezik (interpunkcija itd.).

\section{Socijalna interakcija i kultura}

\section{Osnovni pojmovi komuniciranja u socijalnoj zajednici}

Pojam socijalne kulture možemo definirati kao dio opće kulture, kao sposobnost ljudi da svoje odnose humano urede, te da svoj odnos prema prirodi usklade sa općim prirodnim zakonima s ciljem ostvarivanja slobode i nenasilja. Živjeti u harmoniji sa prirodom i uz uređene socijalne odnose te biti sposoban komunicirati s drugim ljudima, dva su osnovna obilježja socijalne kulture.

Socijalizacija je samo dio čovjekove kulture, samo jedan njen aspekt. Odnos prema prirodi (religiji, umjetnosti i drugim oblicima duhovnog života) i uticaji koji nastaju djelovanjem okoline na čovjeka i čovjeka na okolinu, predstavljaju drugi važan aspekt svake kulture, a posebno komuniciranja u socijalnoj zajednici. Danas se sve češće postavlja pitanje da li je prioritet kulturnog ponašanja u socijalizaciji ili u odnosu čovjeka prema prirodi, a u što svakako spada i sam odnos čovjeka prema drugom čovjeku kao individui. Samo na prvi pogled izgleda da se radi o lažnoj dilemi, ali ako pogledamo savremene radove svjetskih autora, vidjećemo da se odnos prema religiji i umjetnosti znatno zanemaruje, pa i isključuje kada je riječ o socijalnoj interakciji savremenog čovjeka. ${ }^{1}$

Sposobost simbolizacije je omogućila čovjeku da "poima objekte u njihovom odsustvu". Neke od najvažnijih simboličkih tvorevina su: jezik, vjerovanje, umjetnost i vrijednosti. U stvaranju simbola učestvuju različiti elementi u svjesnom i nesvjesnom djelovanju čovjeka, kao što su: razum, volja, imaginacija, osjećanja, želje, potrebe, interesi itd. U

${ }^{1}$ McLuhan, Marshall, Poznavanje opštila ljudskih produžetaka“, BIGZ, Beograd, 1984. 
tom smislu američki teoretičar Lesley Wight ukazuje na činjenicu da bez simboličke komunikacije ljudi uopće ne bi imali kulturu. Pošto je i sam jezik, odnosno govor, uvjetovan dekodiranjem simbola, može se slobodno tvrditi da je kultura nastala u onom trenutku kada je čovjek počeo razumijevati verbalne i neverbalne komunikacijske simbole.

Jezik je najvažnija čovjekova simbolička tvorevina. Prirodni jezik nastao je zbog čovjekove potrebe da se sporazumijeva sa drugim ljudima, zbog upućenosti ljudi na međusobnu saradnju radi stvaranja uvjeta egzistiranja u socijalnoj sredini. Društveni karakter jezika možda se najbolje vidi iz njegove svakodnevne upotrebe. On je instrument međuljudskih kontakata u gotovo svim sferama života i rada čovjeka: $u$ porodici, na poslu, u školi, na putovanju, na odmoru, ili jednom riječju, u svim situacijama u kojima se ljudi susreću i surađuju.

Kada govorimo o jeziku, komunikaciji u socijalnoj ljudskoj zajednici i drugim modelitetima upotrebe jezika, nameće se potreba razlikovanja pojmova jezika i govora. Dihotomija između jezika i govora čini samu bit cjelokupne jezičke djelatnosti, što je odavno u nauci i praksi toliko ukorjenjeno, da njenu teorijsku utemeljenost niko više i ne pokušava provjeravati. Kao što je u jezičkoj nauci poznato, iza svega toga stoji jedan od najvećih lingvista 20. stoljeća, Švicarac Ferdinand de Saussure. On je prvi u modernu lingvistiku unio dihotomiju između jezika i govora. Temeljna podjela jezičke djelatnosti na jezik (lunque) $i$ govor (parole), pruža mnogobrojne mogućnosti interpretacije, ali je za bolje razumijevanje dihotomije najbolje polazište "razlikovanje između vanjskih i unutrašnjih elemenata u jezičnoj djelatnosti."2

De Saussure kao unutrašnje elemente definira sve one jezičke činjenice koje se odnose na jezički sistem, a sve druge činjenice su za njega vanjske. Postoji granica između jezika i govora: jezik je sve što pripada sistemu ( i svaki element koji svojom promjenom izaziva i promjenu u cijelom sistemu dio je jezika, a ne govora). Prema tome, de Saussure nam nudi vrlo jednostavno objašnjenje, šta je jezik, a šta govor. Dakle, jezik je apstraktni sistem znakova (simbola), a govor je njegova realizacija u praksi (konkretizacija onoga dijela jezičke djelatnosti koji nije sam sistem). Jezikom su obuhvaćeni i popis apstraknih znakova,

${ }^{2}$ Škiljan, Dubravko, Govor realnosti i govor jezika,Školska knjiga, Zagreb, 1978. 
kao i njihovi paradigmatski odnosi i propisi o tome kako se ti znakovi kombiniraju u veće cjeline.

Viši nivo poslovne kulture podrazumijeva upotrebu jezika i govora kao jasnog, razumljivog i nedvosmislenog sredstva komuniciranja, u svrhu informiranja partnera $\mathrm{i}$ širenja istine $\mathrm{u}$ javnosti. U poslovnoj kulturi također treba praviti razliku između jezika i govora koji imaju namjeru i cilj da putem reklame i propagande javnost umjesto istinite $\mathrm{i}$ objektivne informacije, dođe u situaciju da mijenja svoje stavove $\mathrm{i}$ uvjerenja o nekom proizvodu. To je glavno obilježje savremenog marketinga, kao i dobrim dijelom, tzv. PR (Public Relations) komunikacija, koje u savremenoj socijalnoj komunikacijskoj interakciji i kulturi prepoznajemo kao djelatnost odnosa s javnošću.

Poslovna kultura predstavlja vrlo specifičnu oblast kulture. Ona nam ukazuje na oblast proizvodnje i poslovnih odnosa u kojima je od primarrne važnosti način organiziranja i realizacije ljudskih međusobnih odnosa. Budući da savremeni socijalni procesi imaju globalizacijsku širinu i zahtjeve, uspješnost društvene grupe i cijele zajednice u najvećoj mjeri zavisi od individualnih znanja i iskustava, kao i međusobnih odnosa i djelovanja. Drugim riječima, poslovnu kulturu grade i stvaraju udruženi pojedinci, koji i pored toga što imaju različita shvatanja, znanja i interese, moraju dogovarati osnovne principe planiranja, rada ili tržišnog komuniciranja.

Poslovna kultura se najčešće definira kao kulturni obrazac ponašanja i institucionaliziranih oblika radnih odnosa koji usmjeravaju cjelokupan način rada unutar jedne poslovne jedinice, omogućavaju interakciju sa drugim poslovnim jedinicama i obezbjeđuju razvoj na individualnom $i$ kolektivnom planu. Osnovni element poslovne kulture je interpersonalna komunikacija. Kroz komunikaciju kao fluidno vezivno tkivo, poslovna komunikacija se prepoznaje u raznolikosti svojih odnosa. Poslovnim komuniciranjem se grade interpersonalni odnosi (odnosi među pojedincima, odnosi pojedinaca prema grupama, idejama). Za dobro funkcioniranje različitih oblika organizacija naročito su bitni grupni socijalni odnosi. Oni su prepoznatljivi po specifičnom duhu zajedništva kao što su, na primjer, timski rad, organizacione jedinice, smjenske grupe, stručne grupe i slično. 
Komunikacijska kultura u socijalnim i drugim društvenim djelatnostima izgrađena je na specifičnim znanjima i iskustvima. Zbog različitih interpersonalnih odnosa u socijalnoj interakciji, profesionalna lica koja rade sa populacijom u stanju socijalne potrebe ili licima koja žive u uvjetima nužne socijalne zaštite, treba da besprijekorno vladaju vrhunskom komunikacijskom kulturom i komunikacijskim vještinama.

Socijalna interakcija u različitim društvenim djelatnostima je često determinirana mnogim faktorima koji narušavaju ili sprečavaju normalno odvijanje interpersonalnog komuniciranja. Pored lošeg komunikološkog znanja iz oblasti sociologije kulture, problem također predstavlja slabo predškolsko obrazovanje, uključujući i nizak nivo kulture govora koji se donosi iz porodice. Komunikacijska kultura ne predstavlja problem samo za jednu stranu u komunikacijskom procesu (u ovom slučaju za osobe u stanju socijalne potrebe), nego i za većinu profesionalnih djelatnika koji nisu prošli odgovarajuću edukaciju iz oblasti društvenog komuniciranja.

\section{OTEŽAVAJUĆI FAKTORI KOMUNIKACIJSKOG PROCESA}

Neverbalni komunikacijski kanali predstavljaju glavni limitirajući faktor komunikativne interakcije. Oni pokazuju misli i emocije, stavove i osobine, kao što također daju i podrška verbalnoj komunikaciji ili predstavljaju zamjenu za nju. Najveći broj ljudi vrlo malo poznaje govor vlastitog tijela, zbog čega postoji nevjerovatna nesrazmjernost između verbalnog i neverbalnog komunikacijskog čina. Govor tijela je vanjski odraz emocionalnog stanja neke osobe. Svaki gest ili pokret može predstavljati dragocjen nagovještaj onoga što osoba u tom trenutku osjeća. Njemački naučnik Eibel Eibsfelt ustanovio je da se izraz osmijeha kod djece koja su rođena gluha ili slijepa pojavljuje nezavisno od učenja i podražavanja, što znači da je to urođeni gest. Ekmann, Freasen I Sorenson u svojim istraživanjima potkrijepili su neka od Darwinovih prvobitnih uvjerenja o urođenim gestovima, proučavajući izraze lica ljudi iz pet veoma različitih kultura. Ustanovili su da sve kulture koriste iste osnovne izraze lica da bi pokazale emocije, što ih je navelo na zaključak da ti gestovi također mora da su urođeni. ${ }^{3}$

3 Pease, Allan\&Barbara,The definitive book of body language,PTY.LTD.,Dorie Simmonds, Australia 
Općenito preovladava mišljenje da su osmijeh i humor najbolji način za uspostavljanje kontakta. Robert Provine je ustanovio da postoji 30 puta veća vjerovatnoća da se smijeh pojavi kada je osoba u društvu nego kada je sama. Smijeh, ustvrdio je, ima manje veze sa vicevima i smiješnim pričama, a više sa građenjem odnosa odnosno, komunikacijske situacije. Smijeh se mnogo češće javlja za vrijeme društvene interakcije. Ovi rezultati pokazali su da se ljudi, što je situacija društvenija, češće smiju, a svaki njihov smijeh traje duže.

Istraživanja u psihologiji komuniciranja insistiraju na razlikovanju smijanja i njegovom shvatanju kao nesvjesnoj reakciji čovjeka na određene individualne i društvene pojave. Za razliku od toga osmijeh je svjesna i kontrolirana reakcija na sve ono što može da doprinese boljoj komunikacijskoj situaciji oba komunikatora. U narodu je poznata izreka , "lijepa riječ i gvozdena vrata otvara" , što na određeni način predstavlja i maksimu za dobru verbalnu komunikaciju. S druge strane, osmijeh predstavlja u neverbalnoj komunikaciji potpuno adekvatan sinonim, za koji se uz to može ustvrditi da je jednako vrijedan kao i svaka lijepa i birana riječ.

Marren Mahleght, profesor marketinga na Koledžu za poslovnu administraciju Univerziteta u Cincinatyju, ustanovila je da ubacivanje humora u reklamu pospješuje prodaju. Utvrdila je da humor povećava vjerovatnoću da će potrošači prihvatiti poruku oglašivača, kao i kredibilitet izvora, tako da komična reklama s poznatom osobom biva još brže prihvaćena. Humor kao oblik interpersonalnog komuniciranja djeluje na konzumenta relaksirajuće, a kao što je poznato potencijalni kupac ili korisnik usluga, najbolje reagira kada je u opuštenom stanju.

Vrlo je malo ljudi koji uopće razmišljaju o tome kako se ponašaju njihove ruke ili o načinu kako se rukuju s nekim. Kad neko počne da se otvara ili bude iskren, vjerovatno će drugoj osobi pokazati dlanove, djelimično ili u cjelini. Poput većine ostalih signala govora tijela, ovo je u potpunosti nesvjestan gest, onaj koji vam pruža intuitivan osjećaj da druga osoba govori istinu. Na suprot tome, skriveni dlanovi mogu da izazovu intuitivan osjećaj da neka osoba ne govori istinu. Ljudski dlan je jedan od rijetkih signala koji se najmanje primjećuje, ali je zato najsnažniji. Dlan emitira snažne impulse kada nekome dajemo uputstva ili naređenja, ili kada se rukujemo. Upotrebljena na odgovarajući način snaga dlana daje onome koji je koristi moć tihog autoriteta. 
U većini kultura klimanje glavom koristi se da bi označilo "da" ili "ne"slaganje sa nekim ili nečim. Smatra se da je to skraćena forma naklona - osoba simbolično kreće da se nakloni, ali to prekine mnogo prije potpunog naklona, što rezultira klimanjem. Naklon je gest potčinjavanja, tako da klimanje glavom pokazuje da se slažemo sa stanovištem druge osobe. Istraživanja koja su obuhvatala ljude gluhe, nijeme i slijepe pokazuju da oni takođe koriste ovaj gest da bi označili "da", tako da izgleda da je posrijedi urođeni gest potčinjavanja. U Indiji se "da" signalizira klaćenjem glavom lijevo - desno. Ovo je zbunjujuće za zapadnjake i Evropljane, koji ovaj znak koriste kada hoće da kažu"možda da -možda ne". Klimanje glavom u Japanu uopće ne znači "da", već obično znači "da, slažem se".

Ovo su samo neki primjeri kako govor tijela može da utiče na našu kulturu komuniciranja. Osim toga, vidi se i sva kompleksnost neverbalne komunikacije kojoj čovjek doista poklanja malu pažnju. U tom smislu treba podsjetiti na glavne kanale neverbalne komunikacije u koje spadaju vizuelne komunikacije (gledanje, kontakti očima i viđenje), zatim izrazi lica (facijalna ekspresija), govor tijela (dodir, držanje tijela, geste glavom i rukama), osobni prostor, prikazivanje sebe i parajezik.

Vizuelna komunikacija se smatra najvažnijim aspektom neverbalnog ponašanja. Ona se ne odnosi samo na gledanje i kontakt očima, nego i na viđenje dostupnih i korisnih socijalnih znakova. Kontakt očima se događa kada oboje ljudi u komunikaciji gledaju jedno drugo u područje očiju. Obično su razdoblja kontakta očima vrlo kratka. Gledanje i kontakt očima sinhronizirani su sa govorom. Kod bilo koje interakcije licem u lice moguće je uzeti tri dimenzije gledanja: trajanje pogleda, broj pogleda i prosječna dužina pogleda. Ovi se parametri u komunikologiji najčešće koriste prilikom uspostavljanja komunikacijskog odnosa između dužine trajanja gledanja odnosno slušanja, odnosno prilikom praćenja distinkcijskih procesa u pogledu verbalnih i neverbalnih ponašanja komunikatora $u$ interpersonalnim odnosima.

Izražavanje emocija izrazima lica odnosno facijalnim izražajima, bilo je proučavano i mnogo prije nego što se komunikološka znanost počela

${ }^{4}$ Hall, Edward, Nemi jezik, BIGZ, Beograd, 1976. 
baviti problemima neverbalnog komuniciranja. Ljudsko lice je najznačajnija i najzagonetnija značajka čovjekovog bića i karaktera. Licem se snažnije i ekspresivnije izražavamo nego riječima. Govor lica (facijalna ekspresija) odaje mnoge tajne ljudskog karaktera i ponašanja. Izrazi lica namjerno ili nesvjesno iskazuju ljudske reakcije na događaje i pojave oko sebe. Facijalni izražaji pod većom su kontrolom čovjeka nego njegovi tjelesni pokreti, koji se teško mogu kontrolirati.

Kao što smo vidjeli iz primjera u uvodu ovog poglavlja, pokreti tijela često odaju čovjekove namjere koje prethode govornom činu, kao i neka obilježja ljudskog karaktera. Govor tijela se razlikuje od drugih neverbalnih komunikacija po svojim dinamičkim manifestacijama (pogled, mimika, gesta, pokreti ruku i nogu) i relativno konstantnim manifestacijam a (dodiri,orijentacija tijela, geste glavom i rukama, pokreti i držanje tijela). Dodir ili općenito tjelesni kontakt varira sa stupnjem intimnosti komunikatora u komunikacijskoj interakciji. Najčešći oblik dodira je rukovanje, koje je uobičajena (očekivana) formalnost pri pozdravljanju i upoznavanju. Dodir se progresivno implicira hvatanjem šake objema rukama, hvatanjem za rame i zagrljajem oko ramena.

Orijentacija tijela je usmjerena prema osobi s kojom pričamo. Kada se spremamo izvesti neku radnju često izvodimo tzv. pripremne pokrete. Oni su nagovještaj onoga što namjeravamo činiti. Držanje tijela uglavnom može biti dobar pokazatelj je li osoba napeta ili opuštena. Geste rukama treba da budu uvijek usklađene sa verbalnom porukom. One također predstavljaju važnu dopunu emocionalnim izrazima lica. Koliko geste rukama mogu biti integrirane sa sadržajem naših verbalnih poruka, najbolje potvrđuje činjenica da često gestikuliramo i kad razgovaramo telefonom.

Osobni prostor ili tzv. diskreciona zona interpersonalne komunikacije predstavlja stupanj fizičke udaljenosti (blizine) komunikatora. Njena validnost uglavnom zavisi od nivoa intimnosti osoba koje se nalaze u komunikativnoj vezi. To su fluidne granice u prostoru koje sa stanovišta bontona odnosno kulture komuniciranja, moraju poštovati kako znanci tako i osobe koje se međusobno ne poznaju. U nekim kulturama narušavanje osobnog prostora smatra se prijetnjom $\mathrm{i}$ krajnje primitivnim činom. Prema američkom komunikologu E. Hallu, postoje četiri zone osobnog prostora i to: intimna zona (do $45 \mathrm{~cm}$ ), osobna zona 
(do $120 \mathrm{~cm}$ ), socijalna zona (120 -360 cm) i javna zona ( preko 360 $\mathrm{cm})$.U pružanju usluga socijalnog rada, osobito u radu sa djecom, važno je poštovati intimnu zonu. Svaki socijalni radnik u svom radu mora uvažavati svog sugovornika, te $u$ toku uspostavljanja prve komunikacije sa štićenikom ( osobom u stanju socijalne potrebe ), važno je da poštuje socijalnu zonu u komunikaciji. Svako približavanje za štićenika, može značiti i davanje poruka nametanja, dominacije, što za sugovornika predstavlja samo poziv za bježanjem.

Važno je navesti, da prikazivanje sebe kao oblik neverbalne komunikacije podrazumijeva kakvu odjeću nosimo, način na koji se češljamo, koju šminku i miris, koristimo, kako i koji nakit koristimo itd. Način na koji predstavljamo sebe u javnosti pruža drugim ljudima s kojima smo u komunikaciji informacije o našem društvenom i poslovnom statusu. Socijalni radnik, socijalni pedagog i sve stručne osobe koje komuniciraju s ljudima u krizi ( osobe koje trebaju pomoć u rješavanju nekih problema, za koje sami ne znaju naći rješenje ), moraju obratiti pažnju na svoje odjevanje. Svako vulgarno odjevanje, ili previše napadno nije primjereno odjeći socijalnog radnika ili socijalnog pedagoga. Način odjevanja mora biti umjeren i jednostavan, primjeren za rad sa ljudima iz vurijabilnih grupa.

Parajezik predstavlja zajednički naziv za sve vidove paralingvističkih oblika u neverbalnoj, a djelimično i verbalnoj komunikaciji. Prvenstveno se veže za parajezičke aspekte govora: visinu, akcenat, vremenski raspon, stanku, emocionalni ton glasa, pogreške u govoru, interpunkciju i slično. Tako, na primjer, intonaciju koristimo da bismo naglasili rečenice. Podižući glas tvrdnju možemo pretvoriti u pitanje, dok brzina govor može biti indikator emocionalnog stresa. Parajezik može odavati osjećaje, sumnju, apatiju, neodlučnost i nesigurnost, ali može biti i kulturni idiom govora.

\section{Zaključak}

Jedno od bitnih određenja kulture komuniciranja jeste da učini lakšim i boljim život čovjeka i njegove U procesu komunikacije u socijalnoj zajednici, kao i u svakom drugom obliku komunikativnih odnosa u društvu, postoje dva subjekta: subjekt koji šalje poruku i subjekt koji prima poruku. Vezivno tkivo komunikacijskog procesa jeste sadržaj poruke (kontekst) koji ima svoje "površinsko" ili formalno značenje i 
svoje "dubinsko" tzv. meta - značenje. Sadržaj poruke je od ključnog značaja, jer njeno formuliranje i razumijevanje u biti određuje smjer komuniciranja.U radu socijalnog radnika i socijalnog pedagoga važni su sadržaji poruke, tj.da li su oni za štićenika razumljivi.U koliko se u neverbalnoj komunikaciji primjeti, da osoba ne razumije sadržaj tvoje poruke, važno ga je pitati, da li želi šire pojašnjenje. Štićeniku se mora dati vremena i pomoći mu da iznese svoje mišljenje o predmetu problema. Cilj razgovora $\mathrm{i}$ jeste da, štićenik mora napustiti mjesto razgovora, $\mathrm{s}$ jasnim porukama dobivenim od strane stručne osobe.

U savremenom poslovnom komuniciranju nema mjesta za alegoričnost i metaforu, kao i skrivene namjere i pobude koje mogu smjer komuniciranja odvesti u pogrešnom pravcu. Jer, današnji globalni svjetski poredak zahtijeva visoku izdiferenciranost sistema poslovnih vrijednosti a koje se u najvećoj mjeri prenose i šire putem poslovnih komunikacija.

Upravo iz pomenutih razloga, interpersonalna komunikologija $u$ savremenom svijetu opterećenom internetskom i digitanom komunikacijom, danas sve više zaokuplja pažnju znanstvenika. Jer, većina njih, pogotovo svjetskih komunikologa, smatra da je humana komunikacija, govor i sposobnost slušanja i empatije, u najvećoj krizi od vremena pojave homo sapiensa. Zbog svega toga danas je potrebno više nego ikada prije posvetiti dužnu pažnju obrazovanju i razvijanju interpersonalne komunikacijske kulture čovjeka tokom čitavog njegovog životrnog vijeka.

\section{LITERATURA}

1. Mc Luhan, Marshall, Poznavanje opštila ljudskih produžetaka, BIGZ, Beograd, 1984; Autor je poznat po svojim futurističkim vizijama koje su prepoznatljive u sintagmama ,globalno selo“ i ,medij je poruka“. $U$ aktuelnom trenutku tzv. informatičke revolucije, predviđanja McLuhana u naučnom diskursu se doživljavaju kao potpuno ostvarenje njegovih ideja i vizija.( str. 2.)

2. Škiljan, Dubravko, Govor realnosti i realnost jezika, Školska knjiga, Zagreb, 1978.; Zagrebački profesor Filozofskog fakulteta D.Škiljan jedan je od najvećih hrvatskih lingvista. On je tvorac tzv. obavijesne teorije koja je utemeljena na istovjetnim leksičkim elementima kao i opća komunikologija. (str.2) 
3. Paese, Allan; Paese, Barbara, The definitive,book of body language, Pty. Ltd., Dorie Simmondt, Cambera, Australien (str. 2)

4. Hall, Edward, Nemi jezik, BIGZ, Beograd, 1976,; Riječ je o jednom od najistaknutijih svjetskih znanstvenika u oblasti neverbalne komunikologije. U svojim knjigama E.Hall je objavio mnoga svoja istraživanja iz područja vizuelnih komunikacija i govora tijela. Naročitu pažnju autor je poklanja istraživanjima o fenomenu parajezika i njegovom uticaju na kulturu humanog komuniciranja. ( str.4)

5. Provine, Robert, is a research professor/professor emeritus at the University of Maryland, Baltimore County, where he studies the development ond evolution the nervos system. (Yawning, Loughing... (Hardeover, 2012.)

6. Vuković, Milorad, Uvod u kulturu komunikacije, Niš, 2006. ( str.3)

7. Tomić, Zorica, Komunikologija, Čigoja štampa, Beograd, 2006. (str-23)

8. Fox, Renata,Poslovna komunikacija, Hrvatska sveučilišna naklada, Zagreb, 2001. (str 4)

9. Suzić, Nenad, Poslovna kultura, BCollege, Banja Luka, 2006. (str. 4)

10. Tucaković, Šemso, Leksikon mas medija,Prosperitet, Sarajevo, 2004. (1-5) 


\section{Emin Mesić, PhD}

University of Bihac

Islamic Pedagogical Faculty

tvusk@net.br

Sena Družić, PhD

University of Bihac

Islamic Pedagogical Faculty

sena_druri@@yahoo.ca

Original scientific article

\section{CULTURE AS A BASIC SOCIAL INTERACTION}

\section{ABSTRACT}

Communication is not only an end in itself, but its purpose in acquiring and articulating knowledge and exchanging the acquired experience. In the field of communication, there are categories which, on the one hand, make the area of finding, registering and transmitting information, while on the other hand communicology attempts to humanize the verbal and non-verbal linguistic discourse to raise the level of human communication to a higher level. The other is the need for the educational process of social work and general work in social activities, provide a higher level of study of interpersonal communication processes and skills.

Keywords: communication, information, interactions, categories, feedback, communication 


$$
\text { الدكتور المحاضر أمين مسيتش }
$$

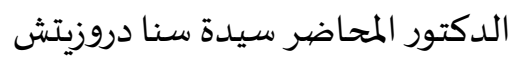

$$
\text { الثقافة كأساس للتفاعل الاجتماعي }
$$

\section{الخلاصة}

التواصل ليس غاية في حد ذاته ولكن الغرض منه في اكتساب المعرفة والتعبير عنها

$$
\text { وتبادل الخبرات المكتسبة. }
$$

هناك فئات من الناس تجعل الاتصالات مجال البحث عن المعلومات وتسجيلها

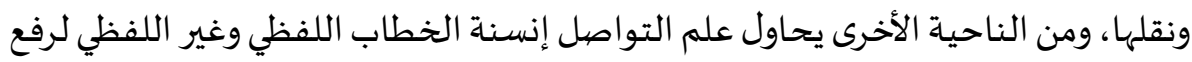

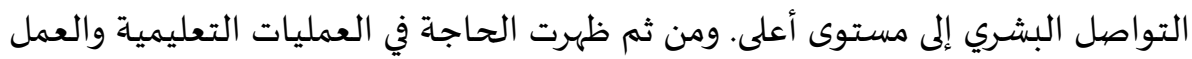

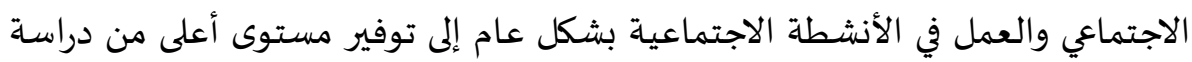
عمليات التواصل المشترك ومهاراتها.

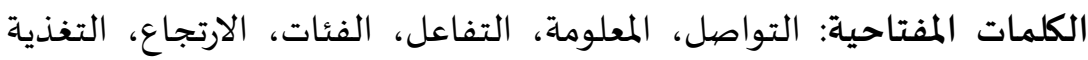

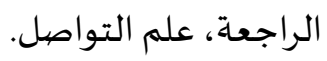

